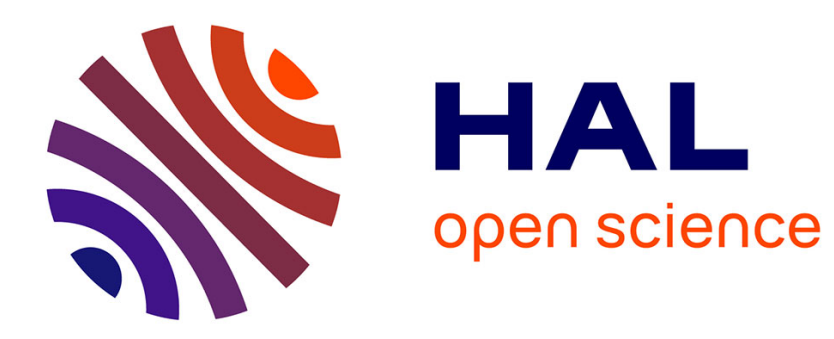

\title{
The upgraded yale MP tandem accelerator
}

K. Sato

\section{To cite this version:}

K. Sato. The upgraded yale MP tandem accelerator. Revue de Physique Appliquée, 1977, 12 (10), pp.1345-1345. 10.1051/rphysap:0197700120100134500 . jpa-00244322

\section{HAL Id: jpa-00244322 https://hal.science/jpa-00244322}

Submitted on 1 Jan 1977

HAL is a multi-disciplinary open access archive for the deposit and dissemination of scientific research documents, whether they are published or not. The documents may come from teaching and research institutions in France or abroad, or from public or private research centers.
L'archive ouverte pluridisciplinaire HAL, est destinée au dépôt et à la diffusion de documents scientifiques de niveau recherche, publiés ou non, émanant des établissements d'enseignement et de recherche français ou étrangers, des laboratoires publics ou privés. 


\title{
THE UPGRADED YALE MP TANDEM ACCELERATOR $\left(^{*}\right)$
}

\author{
K. SATO \\ A. W. Wright Nuclear Structure Laboratory \\ Yale University, New Haven, Connecticut. U.S.A.
}

\begin{abstract}
Résumé - Les performances et le fonctionnement de l'accélérateur MP converti de Yale tels qu'ils ont été observés après les dernières transformations sont décrits.
\end{abstract}

Abstract. - The performance and operation of the upgraded Yale MP accelerator are described.

Following our earlier report [1] on the projected upgrading of our accelerator, the current status and operation of the facility will be discussed.

The accelerator now operates at terminal voltages up to $13 \mathrm{MV}$ and gives every evidence of conditioning to higher voltages. Following the initial modifications described in reference [1], our NEC Pelletron charging system has worked extremely reliably for over 16000 hours with no apparent wear or deterioration. (At the present time our charging current is limited to $\approx 400 \mu \mathrm{A}$ (6 chains); at $13 \mathrm{MV}$ we are using $260 \mu \mathrm{A}$ which is shared among the resistor columns $(80 \mu \mathrm{A}+80 \mu \mathrm{A})$, the control corona $(40 \mu \mathrm{A})$, and losses $(60 \mu \mathrm{A})$ associated with the use of a 4 curie ${ }^{137} \mathrm{Cs}$ radiation source). Our HVEC stainless steel tubes now have over 12000 hours of operation with no tracking or evidence of deterioration beyond the damage which occurred during their initial operation when beam induced radiation fields caused by poor beam transmission resulted in substantial deterioration of the glass at several locations in both the column and the tube in section \#1. (This damage was repaired by grinding off the softened glass and replacing it with epoxy fillets.) Since that time there has been no repetition of this problem. After some initial spark damage to the column resistors, an additional spark gap was designed and installed across each of the $600 \mathrm{M} \Omega / 1200 \mathrm{M} \Omega$ resistor assemblies; this has eliminated this problem. The insulating gas in the

(*) Work supported under USERDA Contract No ГY-76-C-023074 accelerator is a mixture of $33 \% \mathrm{SF}_{6}, 12 \% \mathrm{CO}_{2}$, and $55 \% \mathrm{~N}_{2}$.

Substantial improvements have becn made to the accelerator tube and beam line vacuum by the addition of 2 cryopumps in the terminal and external pumping stations in the adjacent beam lines; during operation the vacuum at the low-energy and high energy ends of the accelerator is typically $5 \times$ $10^{-8}$ torr. Largely as a result of this improved vacuum, our beam transmission is now typically 50-60\% (particles) for beams as heavy as niobium. A second factor in this improved transmission has been several modifications which we have made to the ion optics of our UNIS source to improve its emittance. A second benefit of the improved tube vacuum has been the long term retention of voltage conditioning by the accelerator tubes which operate regularly over the range $2 \mathrm{MV} \leqslant V_{\mathrm{T}} \leqslant 12 \mathrm{MV}$ without the need of any additional reconditioning. Further slow conditioning is expected to move the retention limit to higher voltages. An indication of the present reliability of the accelerator is provided by the fact that over the last 20 months we have been able to run for periods of typically 4 to 6 months between tank openings even during periods of operation at terminal voltages in excess of $12 \mathrm{MV}$.

Inasmuch as we have now had operating experience with a standard MP, an upgraded MP, and an NEC 12 UD [2] some comparative remarks will be presented on the different design philosophies and operational characteristics represented by these three large electrostatic systems.

\section{References}

[1] Sato K., Benjamin J. A., Gingell C. E. L., Parker P. D. and Bromley D. A.. Nucl. Instrum. Methods 122 (1974) 129.
[2] While on leave from Yale and in charge of the installation of the NEC UD machine at Tsukuba University in Japan. 